\title{
THE FLORA OF SOUTH AFRICA I
}

THE general reading public of Great Britain is just beginning to appreciate the fact that the two most interesting regions of Africa after all are the extreme north and the extreme south-Mauretania and Egypt ; Cape Colony, Basutoland, and Natal. And it is curious that between these extremes there is a strange affinity in the more ancient types of human race and mammal. They may, of course, eventually be found connecting links : indisputable remains of a Bushman people in the Sahara, of extinct long-horned buffaloes in Central Africa, and pictographs of cave-dwellers in Katanga, or a fossil, semi-desert flora in East Africa, which may have served as a connecting link between the existing flora of Somaliland and the Sahara on the one hand, and of the Kalahari Desert on the other. Be this as it may, so far as our present knowledge goes, there is a connection between the desert or semi-desert fauna and flora of South Africa and those of the Sahara and Somaliland, which is very puzzling, considering the vast stretch of intervening well-watered area in which no such types can be found living, and none as yet have been revealed in the rocks.

South Africa, as much as any other part of the Continent, is the area of surprising discoveries, which never seem to come to an end. Its palæontology reveals marvel after marvel of vanished types-mastodons coeval with Man, gigantic equines, buffaloes whose horns like those of the Algerian type must have been fourteen feet in length; its palæobotany (as was observed even by Livingstone in the valley of the Zambezi) links us with South America, Antarctica, and Australia, its existing fauna is very reminiscent of Somaliland or of Pleistocene Algeria, the arts of its vanished or vanishing

1 The Flora of South Africa. By Dr. Rudolf Marloth Vol. I. William Wesley and Sons, Essex Street, Strand. 
human races recall those of ancient Mauretania, and its dwindling but still existing flora in north-western South Africa resembles that of the Sahara Desert; while in southern Cape Colony it is of peculiar and remarkable evolution, almost unique, except for a few scattered relations on the loftiest peaks of Central Africa or in temperate South America and Australia. As early as the middle of the eighteenth century the wonders and the amazing beauties of the flora of Cape Colony were appreciated by the scientific men of the day; and the roll of botanists who have made a permanent name and reputation in describing the Cape flora is already a considerable one. Yet to the bulk of us living in Great Britainand even living in South Africa itself-the flora of South Africa is very imperfectly known. Indeed, many must have returned from a hurried journey across the Karoo by rail with the impression that there was very little flora in South Africa to be discussed. Some of the most remarkable of the plants are almost limited in their range at the present day to Table Mountain, to an area scarcely the size of Middlesex.

Lady Phillips (the wife of Sir Lionel Phillips, and the daughter of the late F. A. Ortlepp, a South African naturalist) has rendered a great public service to the world of knowledge by-to put it plainly-financing this splendid enterprise of Dr. Marloth, making it possible for this eminent man to bring out a series of volumes which will treat exhaustively of the South African flora. The volumes apparently are being produced by the Cambridge University Press, to whom a meed of praise is due for the perfection of the colour printing.

The first volume of this work - which I might say at once is of interest to everyone who can read and look at pictures, quite as much as to the scientific botanist-treats first of all of the lowest types of vegetable life-the Fungi and Lichens, and then in turn describes such forms of Liverworts, Mosses, Ferns, Water-ferns, Horsetails, Lycopods, and Cycads, as are found within the land limits of South Africa. (The range of Dr. Marloth's survey extends as far northwards as the Tropic of Capricorn.) A full description is next given of the remarkable Conifers of Cape Colony, to which region in 
South Africa most of the Conifers are restricted in their present range, the only outlying examples being their scarcely recognisable relations, the Gnetacex (Welwitschias). Then we are shown, not only in letterpress but by superb coloured illustrations and photographs from life, and accurate drawings, the truly remarkable Proteas of the South African flora, the Proteas being trees or plants with many-petalled flowers, a group very abundant in other parts of the Southern Hemisphere and including the superb Silver-leaf Tree of Table Mountain. Next come the Figs, the Pepper Trees, the Sandalwoods, the Mistletoes, and the Rafflesias. These last, celebrated in most wonder-books because they include the largest flower in the world, the Raflesia of Sumatra, are represented in Cape flora by some species amazing for their coloration and elaboration of parasitic growth. The volume concludes with an adequate treatment of the Amarants; the Polygons, the Mesembryanthemums, the Caryophyls, Lotuses, Ranunculaceæ, the Poppies, and Crucifers or cabbages. Perhaps the most remarkable section of this last series is that of the Mesembryanthemums, very distant connections of the Cacti of America. All who have visited Kew Gardens must have noticed in the Cactus Houses pot-plants looking like little groups of pebbles or stones that have been broken into blunt fragments at a single blow. Yet these seeming stones are very much thickened leaves, and out of the heart of these grey pebbles will spring flowers of extraordinary loveliness in outline and in colour. One could well imagine a millionaire specialising in mesembryanthemums, and making arrangements for the wealth of South Africa in this respect to be laid discreetly under tribute.

I can only hope that this patriotic effort of Lady Phillips will determine the Government of South Africa henceforth to exercise the most rigid protection over all that remains (for much has been exterminated) of the truly remarkable flora inherited by South Africa, a flora that has many tales to tell to those who can deduce from the evidence it offers the former very different distribution of the land surface in the Southern Hemisphere of this planet.

H. H. JOHNSTON. 